\title{
Pertumbuhan dan Prosentase Molting pada Kepiting Bakau (Scylla semata Forsskäl,1775) dengan Pemberian Stimulasi Molting Berbeda
}

\author{
Ali Djunaedi \\ Departement IImu Kelautan, Fa kultas Perikanan dan IImu Kelautan, Universitas Diponegoro \\ JI. Prof. Soedarto, SH. Ka mpus UNDIP Tembalang, Semarang 50275 \\ Email : a lidjuna edi@ymail.com
}

\begin{abstract}
Abstrak
Produksi kepiting bakau (S. serratta Forsskäl, 1775) sangat dipengaruhi oleh pertumbuhan, tingkat kelulushidupan dan prosentase moulting. Studi tentang pengaruh metode perangsangan moulting kepiting bakau merupakan salah satu usaha untuk meningkatkan produksi. Penelitian ini bertujuan untuk mengetahui pengaruh berbagai metode perangsangan moulting terhadap prosentase moulting, kelulushidupan dan pertumbuhan. Penelitian menggunakan metode eksperimental dengan Rancangan Acak Lengkap (RAL). Penelitian mengguna kan biota uji 120 ekor kepiting bakau (S. serrata Forsskäl, 1775) betina. Perlakuan metode perangsangan moulting yaitu, ablasi, autotomi dan penyuntikan homon ovaprim dan kontrol, masing-masing diulang 3 kali. Pengamatan dilakukan pada, persentase moulting, kelulushidupan, pertumbuhan dan kualitas air. Hasil penelitian menunjukkan bahwa terdapat perbedaaan sangat nyata $(p>0,01)$ pada berbagai perlakuan metode perangsangan moulting terhadap persentase moulting, kelulushidupan dan pertumbuhan. Perlakuan metode ablasi menunjukkan hasil paling tinggi, dengan persentase moulting $80 \pm 10 \%$, kelulushidupan $83,34 \pm 5,78 \%$ dan laju pertumbuhan spesifik harian 5,36 $\pm 0,34 \%$ hari. Sedangkan hasil terendah dicapai oleh perlakuan metode a utotomi dengan persentase moulting 13,33 $\pm 5,78 \%$, kelulushidupan $16,67 \pm 5,7 \%$ dan laju pertumbuhan spesifik harian $1,81 \pm 0,22 \%$ hari. Metode ablasi mata baik untuk diterapkan dalam merangsang moulting di dalam pemeliharaan kepiting bakau guna menunjang peningkatan produksi.
\end{abstract}

Kata Kunci : Kepiting bakau, Scylla serratta, Kelulushidupan, Moulting, Pertumbuhan

Abstract

Production of mud crab (S. serratta Forsskål, 1775) influenced by moulting, the growth and survival rate. Study of effects of stimulation of moulting on mud crab cultivation are important. The objective of the research was influence of various stimulation method on percentage of moulting, growth and survival rate. The method used experimentally laboratories with complete random design. The mud crab (S. serrata Forsskål, 1775) females was used as treatment biota. There were given various treatment methods which moulting stimulation, ablation, autotomi, injection homone ovaprim and controls each 3 times replicated. Observations were made of the percentage moulting, survival rate, growth rate and water quality parameter. The results showed that there are highly signific ant $(p \varangle 0.01)$ in the various treatment methods of stimulation moulting on the percentage moulting, growth and survival rate. Ablation treatment method showed the highest result, where moulting percentage is $80 \pm 10 \%$, survival rate $83.34 \pm 5.78 \%$ and the specific growth rate of $5.36 \pm 0.34 \%$ / day. While the lowest is autotomi method with moulting percentage is $13.33 \pm 5.78 \%$, surviva I rate $16.67 \pm 5.7 \%$ and the specific growth rate of $1.81 \pm 0.22 \%$ day. Ablation method is good to stimulate of moulting in the cultivation of mud crabs to inc reased production.

Keywords: Mud crab, Scylla serratta, Survival Rate, Moulting, Growth. 


\section{PENDAHULUAN}

Kepiting bakau merupakan komoditi ekspor yang masih prospetif terutama produk dalam bentuk kepiting soka (soft shell crab). Akan tetapi sampai saat ini masih banyak kendala yang dihadapi antara la in waktu ganti kulit a tau molting yang tidak serentak dan periode pemeliharaan yang relatif lama serta tingginya angka kematian. Hal tersebut akan berakibat tidak pastinya produksi dan biaya pemeliharaan yang tidak efisien.

Berbagai penelitian telah dilakukan untuk mengatasi masalah tersebut, antara lain stimulasi dengan pakan, lingkungan dan dengan pemotongan kaki (Fujaya, 2009). Namun hasilnya masih belum seperti yang diharapkan. Masalah utama di dalam produksi budidaya pemeliharaan kepiting bakau, terutama kepiting soka atau kepiting lunak ditentukan oleh berbagai faktor, di antaranya pertumbuhan, kelulushidupan dan tingkat moulting. Faktor kelulushidupan sangat penting karena kepiting dijual dengan satuan ekor. Sedangkan kepiting moulting (soka) mempunyai nilai jual yang lebih tinggi dari pada kepiting yang tidak moulting.

Faktor-faktor yang mempengaruhi tingkat produksi dalam suatu usaha budidaya kepiting soka adalah prosentase moulting, laju pertumbuhan dan kelangsungan hidup (Kanna, 2000). dan Faktor-faktor tersebut dipengaruhi oleh faktor intemal dan ekstemal (Kordi, 2000). Faktor intemal meliputi keturunan, umur, kecepatan pertumbuhan relatif, jenis kelamin, reproduksi, ketahanan terhadap penyakit dan kemampuan untuk memanfaatkan pakan. Sedangkan faktor ekstemal meliputi kualitas air, kepadatan dan jumlah serta komposisi asam amino/protein yang terkandung dalam pakan.

Kepiting bakau (S.serrata Forsskäl, 1775) akan mengalami pergantian kulit sebanyak 18 kali dari stadia instar sampai dewasa. Secara umum frekuensi pergantian kulit lebih sening terjadi pada stadia awal dibandingkan stadia dewasa, dengan demikian kesempatan tumbuh kepiting terjadi saat kepiting muda (Hanafi, 1992).

Secara fisiologis, pertumbuhan dan proses moulting kepiting bakau dipengaruhi oleh faktor fisiologis baik secara langsung dan tak langsung. Pengaruh langsung dilakukan dengan pemberian homon (Bliss, 1983). Kontrol homon pada kepiting dipengaruhi oleh adanya homon penghambat di antaranya homon penghambat metobolisme, hormon penghambat moulting (MIH) dan homon penghambat perkembangan gonad (GIH) (Carlisle, 1953). Sedangkan cara fisiologi tak langsung dilakukan dengan metode autotomi atau ablasi (Kanna, 2000). Oleh karena itu, studi tentang pengaruh metode perangsangan moulting dalam pengembangan usaha budidaya kepiting bakau secara intensif perlu dilakukan.

\section{MATERI DAN METODE}

Biota uji yang akan digunakan adalah 120 ekor kepiting bakau (S. serrata Forsskäl,1775) betina dengan bobot $80 \pm 2$ g. Kondisi kepiting sehat dan aktif serta lengkap anggota tubuhnya. Kepiting didapatkan dari pengepul di Desa Dana Sari, Kecamatan Petarukan, Kabupaten Pemalang. Kepiting terlebih dahulu dilakukan adaptasi terhadap kondisi yang ada di dalam bak pemeliharaan selama lebih kurang 5 hari (Sia ha inenia, 2004).

$\mathrm{m}^{3} \begin{gathered}\text { Dua belas bak berukuran } 1 \times 1 \times 1 \\ \text { digunakan sebagai tempat }\end{gathered}$
pemeliharaan kepiting dan wadah keranjang apung berukuran $30 \times 15 \times 15$ $\mathrm{cm}$ yang terbuat dari plastik bagian atasnya ditutup dengan anyaman bambu. Setiap bak diisi sepuluh ekor kepiting. Pemeliharaan dilakukan dengan sistem batera i.

Media uji berupa air laut yang diambil langsung dari saluran tambak dengan menggunakan pompa air yang dilengkapi sistem saringan pasir. Sedangkan pakan yang diberikan yaitu 
potongan ikan rucah dengan ransum pemberian pakan dengan sebesar $5 \%$ dari berat tubuh dan diberikan dua kali sehari.

Metode yang digunakan dalam penelitian ini adalah metode eksperimental. Penelitian menggunakan rancangan acak lengkap (RAL) dengan 4 perlakuan perbedaan metode stimulasi moulting yaitu dengan ablasi (pemotongan tangkai mata), utotomi (pemotongan kaki), hormon (penyuntikan homon reproduksi) dan tanpa stimulasi sebagai kontrol, masing-masing diulang 3 kali. Parameter yang diamati adalah pertumbuhan, persentase moulting dan kelulushidupan. Pengamatan moulting dilakukan setiap hari, sedangan pertumbuhan dan parameter kualitas air dilakukan setiap minggu.

Pelaksanaan penelitian dimulai dengan pengumpulan alat dan bahan, serta adaptasi biota uji. Setelah semua persiapan penelitian selesai diakukan, kemudian biota uji diberi perlakuan sesuai dengan metode stimulasi masing-masing. Selanjutnya setiap kepiting yang telah diberi perlakuan dimasukkan kedalam keranjang dan ditempatkan pada 1 bak untuk 10 buah keranjang. Pemberian pakan dilakukan pada pagi dan sore hari setelah dilakukan penyiponan. Sedangkan pergantian air dilakukan setiap minggu. Pemeliharaan dilakukan selama 5 minggu. Setiap minggu dilakukan penimbangan berat kepiting, penghitungan prosentase molting dan prosentase kelulushidupan.

\section{Pertumbuhan}

Pengamatan pertumbuhan didasarkan pada laju pertumbuhan spesifik harian didapatkan melalui perhitungan penimbangan berat tubuh secara gravimetri. Laju pertumbuhan spesifik harian dapat ditentukan dengan menggunakan rumus, (Changbo et al., 2004) :

$$
\mathrm{LPH}=\left(\left(\ln \mathrm{W}_{\mathrm{t}}-\ln \mathrm{W}_{0}\right) \times 100\right) / \mathrm{t}
$$

Di mana:

$\mathrm{LPH}=$ Laju pertumbuhan berat spesifik harian (\%/hari)

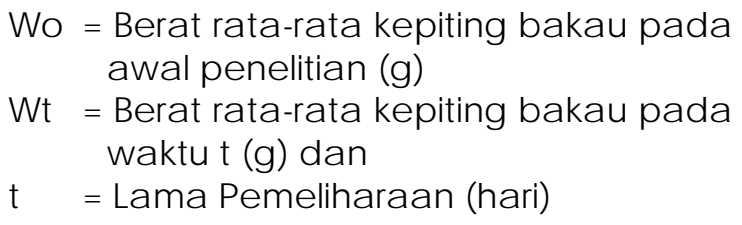

\section{Prosentase Moulting}

Pengamatan moulting dilakukan setiap minggu dengan menghitung berapa jumlah kepiting yang ganti kulit (moulting). Kemudian dihitung prosentasenya.

\section{Kelulushidupan}

Pengamatan tingkat kelulushidupan dapat ditentukan dengan menghitung berapa jumlah awal/ total kepiting tiap bak pemeliharaan yang masih hidup dan berapa jumlah kepiting yang mati pada sa at pengamatan.

\section{Parameter Lingkungan}

Parameter lingkungan yang diukur mencakup beberapa parameter kualitas air. Parameter tersebut, antara la in: suhu, pH (derajat keasaman), salinitas, amonia, DO. Pengukuran parameter temperatur, $\mathrm{pH}$, dan salinitas dilakukan dengan interval waktu pengamatan tiga kali tiap 12 jam, yaitu pada pukul 06.00 dan 18.00 WIB dalam 24 jam. Penentuan kadar amoniak dan DO dilakukan setiap satu minggu sekali sela ma 5 minggu.

\section{Analisis Data}

Data parameter pengamatan penelitian, yaitu data laju pertumbuhan, moulting, dan kelulushidupan spesifik harian dianalisis menggunakan ANOVA (Analisis Varians) untuk menentukan perbedaan pengaruh masing - masing perlakuan. Untuk mengetahui perbedaan pengaruh perlakuan diuji dengan uji beda nyata jujur atau HSD (Santoso, 2004). Data parameter lingkungan dia na lisis sec a ra diskriptif.

\section{HASILDAN PEMBAHASAN}

Laju pertumbuhan spesifik harian S. serrata Forsskäl, 1775 dari yang paling 
tinggi secara beruntan adalah perlakuan ablasi sebesar 5,36 $\pm 0,34 \%$ hari, penyuntikan hormon mencapai 3,72 \pm $0,55 \%$ hari , kontrol menunjukkan hasil sebesar 2,49 $\pm 0,41 \%$ hari, dan perlakuan autotomi sebesar $1,81 \pm 0,22 \%$ hari ( Gambar 1).

Hasil a nalisis menunjukkan laju pertumbuhan spesifik harian S. serrata Forsskäl, 1775 pada metode ablasi menunjukkan hasil yang tinggi dibandingkan dengan metode autotomi dan penyuntikan homone ( Gambar 1). $\mathrm{Hal}$ ini sesuai dengan hasil penelitian Siahainenia (2000), yang menyatakan bahwa kepiting yang diberi perlakuan ablasi mempunyai laju pertumbuhan dan tingkat kematangan gonad yang lebih tinggi dari pada kepiting yang tidak dilakukan ablasi.

Pertumbuhan kepiting dengan metode ablasi lebih tinggi karena mempunyai jumlah moulting yang lebih banyak dari metode lainnya. Sedangkan pada saat moulting, terjadi peningkatan pertumbuhan yang cukup besar baik pertumbuhan ukuran panjang, lebar maupun beratnya. Menurut Hartnoll (2004), pertumbuhan krustasea dipengaruhi oleh kontrol homon, yaitu homon moulting, pengaruh rangsangan dari luar dan umur. Menurut Bliss (1983), menyatakan bahwa pertumbuhan krustasea dipengaruhi oleh beberapa kontrol hormon, di antaranya homon moulting dan homon penghambat moulting. Homon tersebut banyak diproduksi dalam tangkai mata. Menurut Soyez dan Kleinholz (2005), dalam tangkai mata tersebut terdapat $\mathrm{X}$-organ yang dapat menghambat pertumbuhan, moulting dan kematangan gonad. Metode ablasi dilakukan dengan menghilangkan salah satu tangkai mata. Penghilangan organ tersebut berakibat tidak terbentuknya hormon penghambat pertumbuhan (Anggoro, 2001).

Sedangkan perlakuan autotomi laju pertumbuhannya lebih rendah, hal tersebut dikarenakan pemotongan capit dan kaki jalan bertujuan hanya untuk merangsang pertumbuhan organ yang baru. Metode autotomi hanya melukai capit dan menghilangkan kaki jalan namun tangkai mata masih utuh sehingga homon penghambat yang disekresikan oleh organ masih terbentuk dan menghambat laju pertumbuhan. Hal sama terjadi pada metode penyuntikan homon yang biasanya dilakukan untuk menstimulasi perkembangangonad dalam pemijahan sehingga mempercepat pertumbuhan melalui proses moulting. Menurut Moosa dkk. (1985), menyatakan bahwa kepiting yang akan melakukan perkawinan setelah matang gonad didahului oleh proses moulting. Metode ini memang bertujuan untuk mempercepat pertumbuhan melalui proses moulting namun hormon penghambat yang dihasilkan dari sekresi X-organ masih

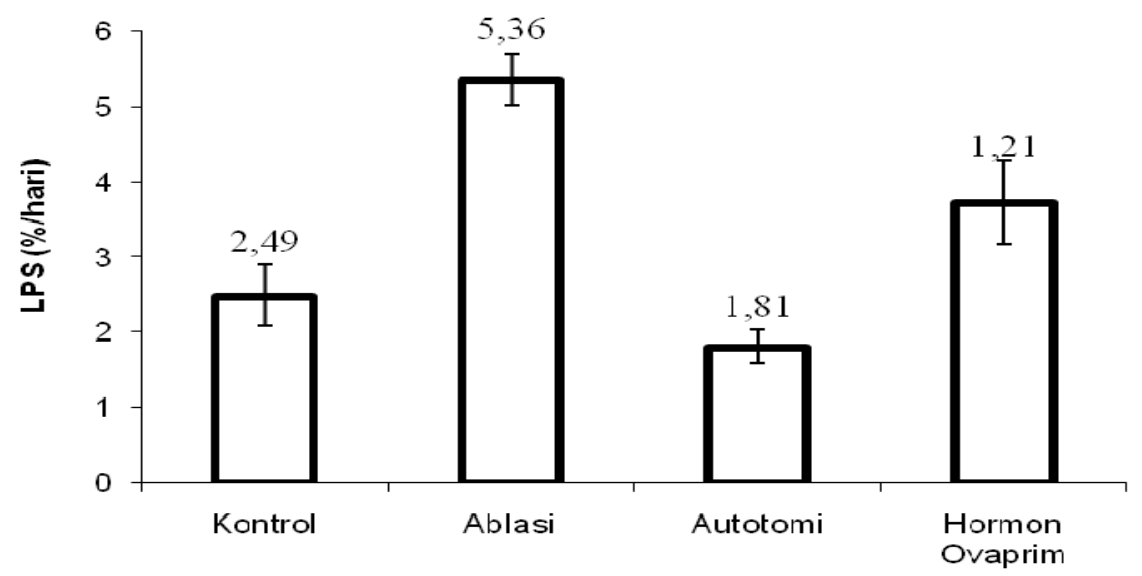

Gambar 1. Rerata Laju Pertumbuhan Spesifik S. serrata Forsskäl, 1775 
terbentuk sehingga menghambat laju pertumbuhan seperti halnya pada metode autotomi.

Pertumbuhan melalui proses moulting pada metode ablasi terjadi pada minggu ke tiga. Hal ini sesuai dengan hasil penelitian Afrizal (2009), yang menyatakan bahwa kepiting mengalami masa moulting atau ganti kulit 15-20 hari. Lebih lanjut, Siahainenia (2000), menyatakan kepiting dalam pertumbuhan siklus hidupnya mengalami moulting 2-5 kali dalam waktu 3-4 bulan. Dengan terjadinya proses moulting pada minggu ke tiga maka berat kepiting $\mathrm{S}$. serrata Forsskäl, 1775 pada minggu ini akan mengalami peningkatan karena pada proses moulting terjadi pertambahan berat dan lebarkarapas.

\section{Prosentase Moulting}

Persentase moulting rata-rata $\mathrm{S}$. serrata Forsskäl, 1775 di dalam pemeliharaan selama lima minggu dengan berbagai metode stimulasi moulting pada perlakuan kontrol menunjukkan persentase moulting ratarata $16,67 \pm 5,78 \%$. Moulting terjadi pada minggu ke dua dan ke tiga dengan persentase tingkat moulting 10 dan $6,7 \%$. Perlakuan kontrol pada minggu pertama, minggu ke empat dan minggu ke lima tidak terja di moulting.

Berdasarkan hasil analisis statistik, perlakuan stimulasi moulting berpengaruh sangat nyata $(p<0,01)$ terhadap tingkat moulting (Tabel 1). Hasil penelitian menunjukkan moulting terjadi setelah minggu pertama dan mencapai puncak pada minggu ke tiga dan minggu ke empat masa pemeliharaan. Persentase moulting individu yang tertinggi dicapai dengan metode ablasi. Menurut Carlisle (1953), dalam tangkai mata krustasea terdapat homon yang dapat menghambat moulting dan perkembangan gonad. Oleh karena itu, dengan adanya penghilangan X-organ penghasil homon penghambat moulting di tangkai mata melalui proses ablasi dapat lebih meningkatkan jumlah kejadian moulting pada kepiting yang dibudidayakan. Proses keja metode ablasi langsung ke target organ, yaitu dengan menghilangkan tangkai mata sebagai organ penghasil hormon penghambat moulting sehingga proses kerja moulting menjadi cepat. Metode autotomi dilakukan dengan melukai capit dan memotong kaki jalan tetapi tangkai mata masih utuh, sehingga hormon penghambat moulting masih terbentuk. Metode autotomi juga menyebabkan stres karena rasa sakit akibat perlakuan lebih besar daripada perlakuan metode lain, yakni pemotongan capit dan kaki jalan. Hal ini mengharuskan kepiting melakukan penyembuhan kembali dalam pembentukan individu baru.

Metode penyuntikan hormon ovaprim menstimulasi perkembangan gonad untuk mempercepat proses moulting karena kepiting yang matang gonad, sebelum melakukan pemijahan

Tabel 1. Persentase moulting individu S. serrata Forsskäl, 1775 dengan berbagai metode perangsangan moulting selama penelitian

\begin{tabular}{ccccc}
\hline Minggu ke & \multicolumn{5}{c}{ Persentase Moulting (\%) } \\
\cline { 2 - 5 } & Kontrol & Ablasi & Autotomi & Ovaprim \\
\hline 1 & 0 & 6,7 & 3,3 & 0 \\
2 & 10 & 20 & 3,3 & 0 \\
3 & 6,7 & 43,3 & 6,7 & 13,3 \\
4 & 0 & 10 & 0 & 46,7 \\
5 & 0 & 0 & 0 & 0 \\
\hline J umlah & $16,67 \pm 5,78$ & $80 \pm 10$ & $13,33 \pm 5,78$ & $60 \pm 10$ \\
\hline
\end{tabular}


terlebih dahulu melakukan proses moulting (Moosa dkk.,1985). Oleh karena itu, penggunaan homon ini tepat dilakukan dalam menstimualsi kematangan gonad dan proses pemijahan kepiting. Dengan demikian, pemberian hormon ovaprim juga dapat menstimulasi proses moulting. Proses kerja homon memerlukan waktu untuk merangsang target organ sementara tangkai mata sebagai penghasil hormon penghambat moulting masih utuh. Dengan demikian, homon penghambat moulting juga masih terbentuk. Hal ini memperlambat terjadinya proses moulting.

Proses ganti kulit (moulting) kepiting memerlukan energi dan gerakan yang cukup kuat, maka bagi kepiting dewasa yang mengalami pergantian kulit membutuhkan energi dari pakan yang cukup besar. Jumlah kandungan nutrisi yang dihasilkan dari pakan yang diberikan mencukupi bagi kepiting untuk melakukan proses moulting. Lebih lanjut Borgstrom (2002), mengemukakan bahwa sebagai orga nisme yang berhubungan dengan a ir, kepiting memperoleh energi dari makanan yang mereka dapatkan. Apabila kandungan energi berkurang maka protein dalam tubuh akan dipecah dan dipergunakan sebaga i sumber energi. Energi yang diperlukan dalam proses moulting cukup besar, Jika protein dipakai sebagi sumber energi tidak mencukupi maka hal tersebut juga dapat menyebkan kematian kepiting pada saat moulting.

\section{Kelulushidupan}

Hasil penelitian menunjukkan bahwa kelulushidupan tertinggi dicapai oleh perlakuan ablasi (Gambar 2). Hal ini diduga dika renakan luka akibat perlakuan pada metode ablasi lebih kecil dari pada luka pada perlakuan metode autotomi, sehingga metode Autotomi, mempunyai tingkat kelulushidupan paling rendah. Kelulushidupan terendah pada metode autotomi terjadi di minggu pertama dan ke dua. Perbedaan tingkat kelulushidupan disebabkan oleh beberapa faktor, di antaranya tingkat stres yang diakibatkan karena luka yang diterima kepiting. Luka yang didapat pada metode autotomi membuat kepiting perlu waktu yang lebih lama untuk pemulihan kondisinya. Luka ini dapat juga menyebabkan tejadinya infeksi karena adanya bakteri yang terdapat dalam media a ir laut dan bakteri yang berasal dari sisa pakan sehingga menyebabkan kematian (Department of Ocean Development, 1999). Menunut Malik (2009) berpendapat bahwa kepiting yang sudah stress, keseimbangan fisiolog is tubuhnya pun terganggu, sehingga daya tahan tubuhnya menurun, memberi peluang terhadap parasit, virus dan fluktuasi kualitas air untuk masuk dan merusak fungsi fisiologis pada kepiting sehingga dapat menyebabkan kematian. Menurut Husni (2006) dalam Afrizal (2009) yang menyatakan bahwa secara biologis pematahan capit dan kaki jalan dapat merangsang organ tubuh kepiting untuk tumbuh kembali. Hal ini disebabkan setelah capit dan kaki jalan kepiting lepas, kepiting akan terangsang untuk memperbaiki fungsi morfologi tubuhnya dengan cara melakukan pergantian kulit sehingga akan menjadi kepiting cangkang lunak.

Pemotongan capit kaki atau autotomi bertujuan untuk meningkatkan hormon yang dapat menimbulkan ketidakseimbangan atau stress sehingga kepiting akan merespon untuk melakukan regenerasi dengan cara moulting, namun tingkat stress pada kepiting juga dapat menyebabkan kematian. Selain hal tersebut, faktor moulting juga berpengaruh terhadap tingkat kelulushidupan. Proses moulting yang lebih pendek dari interval moulting, maka akan meningkatkan homon ketidakseimbangan atau stress sehingga menyebabkan kematian. Disamping itu juga kepiting yang mengalami moulting memerlukan energi untuk prosesnya (Phelan dan Grubert, 2007). Hal ini juga dapat mengakibatkan kematian karena energi yang diperlukan cukup besar. Faktor yang mempengaruhi tingkat kelulushidupan antara la in dinyatakan dalam dua hal yaitu, faktor biotik seperti kompetitor, predator, kepadatan populasi, parasit, penyakit, virus dan bakteri serta faktor abiotik, yang meliputi faktor fisika dan kimia. 


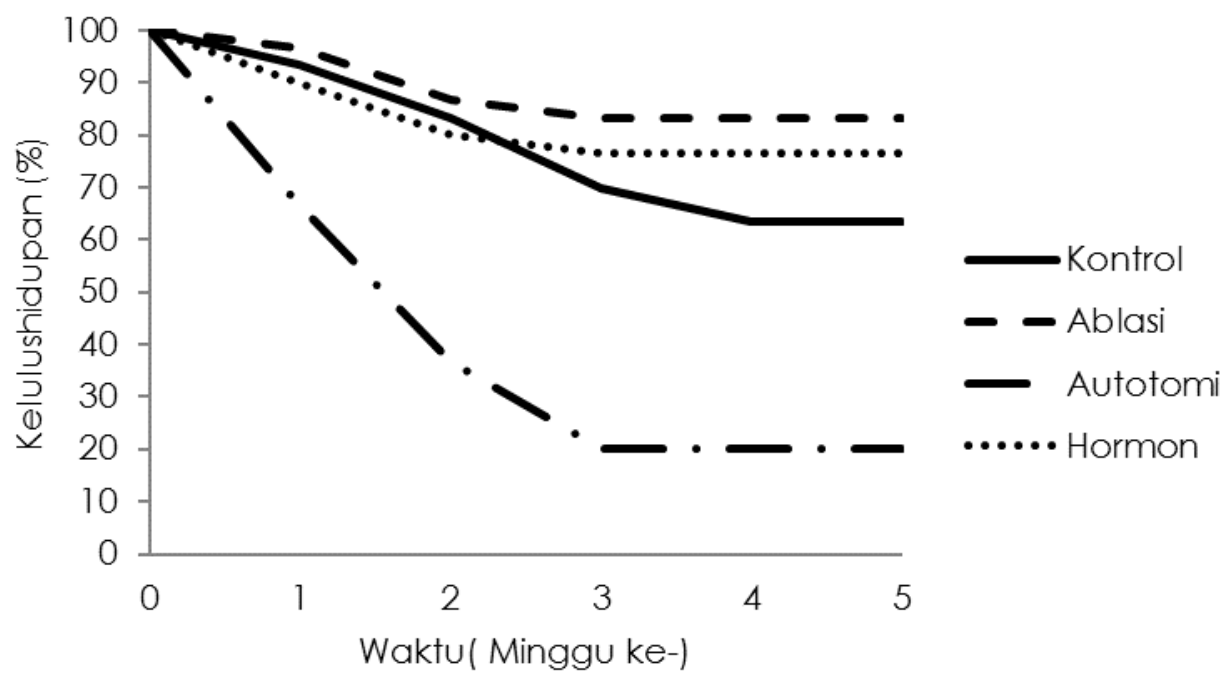

Gambar 2. Kelulushidupan S. serrata Forsskäl, 1775

Kualitas air pada media pemeliharaan selama pengamatan masih dalam kisaran nomal dengan suhu ratarata $28^{\circ} \mathrm{C}$, salinitas $28 \mathrm{~g} / \mathrm{L}, \mathrm{pH} 7$, oksigen terlarut kisa ran 5,13-8,29 mg/L dan a monia kisaran 0,239-0544 mg/L Kond isi kua litas a ir pada media pemeliharaan layak untuk memenuhi kebutuhan kualitas air bagi kepiting untuk hidup.

\section{KESIMPULAN}

Berdasarkan hasil penelitian dapat disimpulkan, bahwa perbedaan metode perangsangan moulting berpengaruh terhadap persentase moulting, kelulushidupan dan pertumbuhan $\mathrm{S}$. serrata Forsskål, 1775. Persenta se moulting, kelulushidupan dan Laju pertumbuhan spesifik harian tertinggi dicapai pada metode ablasi (persentase moulting $80 \pm$ $10 \%$, dan kelulushidupan $83,34 \pm 5,78 \%$, LPS $5,36 \pm 0,34 \%$ hari). Sedangkan laju pertumbuhan spesifik harian, tingkat moulting dan kelulushidupan terendah dicapai oleh metode autotomi (LPS 1,81 \pm $0,22 \%$ hari, persentase moulting 13,33 \pm $5,78 \%$, dan kelulushidupan $16,67 \pm 5,78 \%$ ).

\section{DAFTAR PUSTAKA}

Afrizal, H. 2009. Teknik pemoultingan kepiting (Scylla sp.) cangkang lunak dan penanganan hasil panen. Sekolah Tinggi Perikanan Jakarta, 30$36 \mathrm{hlm}$.

Anggoro, S. 2001. Peran hidrobiologi dalam pengembangan perikanan pantai. Fakultas Perikanan dan IImu Kelautan, Universitas Diponegoro Semarang, $\quad 20-21 \mathrm{hlm}$.

Azis. 2008. Perangsangan moulting pascalarva lobster air tawar jenis capit merah (Cherax quadricarinatus, Von Martens) dengan perlakuan suhu. Tesis. Program Studi llmu Perairan, Sekolah Pasca Sarjana, Institut Pertanian Bogor, 5-17 hlm.

Bliss, Dorothy. E. 1983. The Biology of Crustacea. Vol.8 Environmental Adaptations. Academic Press, New York, $198 \mathrm{p}$.

Carlisle, D. B. 1953. Moulting hormone in Leander (Crustacea Decapoda). Mar. biol., Ass. United Kingdom, 32:95-289 pp.

Chang, E. S. and Snyder, M.J . 1986. Effect of eyestalk ablation on larval molting rates morphological development of the American lobster (Homarus americ a nus). Biol., Bull., 170: 232-243.

Changbo, Z, D. Shuanglin, W. Fang \& H. Guoqiang. 2004. Effects of $\mathrm{Na} / \mathrm{K}$ ratio in seawater on growth and energy budget of juvenile Litopenaeus vannamei. Aquac ulture, 234: 485-496.

Department of Ocean Development. 1999. Fattening of spiny lobster 
Panulinus homarus, $P$. versic olor and mud crab (Scylla serrata) using different pelletised and live feeds (mussels, clams, squids, trash fish and chicken waste) both in the main land and Islands Development, National Institute of Ocean Technology, Chennai,12: 235-238.

Gunarto and Cholik, F. 1990. Effect of stocking densities on mangrove crab (S. serrata) in ponds. Coastal Aquaculture., Maros, South Sulawesi, Indonesia, 3(2): 60-64.

Hartnol, R G. 2004. Growth in Crustacea Twenty Years on. Hidrobiologia J oumal, 449(1-3): 111-122.

Huynh, M.S \& R. Fotedar. 2004. Growth, survival, hemolymph osmolality and organosomatic indices of the westem king prawn (Penaeus laticulatus Kihinouye, 1896) reared at different sa linities. Aqua c ulture, 234: 601-614.

Irawan, B dan Agus Soegianto. 2004. Kekayaan jenis portunidae di sisi shipping line selat Madura. Jumal
Penelitian Universitas Airlangga Surabaya, 14(1):33-35.

Kanna, I. 2000. Hormon Penghambat Moulting (MIH dan GIH) dalam Pembenihan dan Pembesaran Kepiting Bakau, Kanisius, Jakarta, 30$32 \mathrm{hlm}$.

Kasry, A. 1991. Pengaruh antibiotik dan makanan terhadap kelulushidupan dan perkembangan larva kepiting bakau (Scylla serrata Forsskäl). Jumal Penelitian Institut Pertanian Bogor, 12(2): 568-570.

Kordi, M.G.K. 2000. Budidaya Kepiting dan Bandeng di Tambak Sistem Polikultur. Dahara Prize. Semarang. 11-37 hlm.

Majid, A.H., S.Nader. A. Azadeh and B. Ahmad. 2008. Influence of eyetalk ablation and temperature on molting and mortality of Narrow-clawed Crayfish. Hid robiology, $8: 219-223$.

Phelan, M. Grubert, M. 2007. The life cycle of the mud crab. Coastal Research Unit. Darwin, Nothem Territory Govemment. 11: 1-5. 